Article history: Submitted 8 April 2021; Accepted 30 May 2021; Available online 1 June 2021.

\title{
Kedudukan Kreditor yang Tidak Terdaftar Pada Putusan Perdamaian PKPU Dalam Mengajukan Permohonan Pernyataan Pailit
}

\author{
Adam Barnini, Nyulistiowati Suryanti dan Artaji \\ adam17002@mail.unpad.ac.id \\ Universitas Padjadjaran
}

\begin{abstract}
Keywords: $\quad$ Abstract
Suspension of This article will examine the position of creditors who are not registered in the peace Obligation For agreement that has been ratified in filing a bankruptcy statement and the strength of the

Payment Of Debt; homologation decision against creditors who are not registered in the peace agreement. Homologation The research method used is juridical normative by referring to written legal materials by Decision; Creditors reviewing secondary data in the form of primary, secondary and tertiary legal materials are Not Registered relating to bankruptcy and suspension of payment. The results of this study conclude in the Peace that first, creditors who feel disadvantaged because they are not registered in the peace Agreement. agreement cannot file a bankruptcy statement. Second, the homologation decision still has legal force against creditors who are not registered in the homologation decision.
\end{abstract}

\section{Kata Kunci: $\quad$ Abstrak}

PKPU; Putusan Penelitian ini akan membahas mengenai kedudukan kreditor yang tidak Homologasi; Kreditor Tidak Terdaftar dalam Perjanjian Perdamaian. terdaftar dalam perjanjian perdamaian yang telah disahkan dalam mengajukan permohonan pernyataan pailit dan kekuatan putusan homologasi terhadap kreditor yang tidak terdaftar dalam perjanjian perdamaian. Metode penelitian yang digunakan adalah yuridis normatif dengan merujuk pada bahan-bahan hukum tertulis dengan mengkaji data sekunder yang berupa bahan hukum primer, sekunder dan tersier yang berkaitan dengan kepailitan dan PKPU. Hasil penelitian ini menyimpulkan bahwa pertama, terhadap kreditor yang merasa dirugikan karena tidak terdaftar dalam perjanjian perdamaian tidak dapat mengajukan permohonan pernyataan pailit. Kedua, putusan homologasi tetap memiliki kekuatan hukum terhadap kreditor yang tidak terdaftar dalam putusan homologasi.

Copyright (c) 2021 Adam Barnini, Nyulistiowati Suryanti dan Artaji. (c)(1)(2) Published in Media Iuris. Published by Universitas Airlangga, Magister Ilmu Hukum.

\section{Pendahuluan}

Perorangan maupun perusahaan dalam menjalankan kegiatan ekonomi pasti membutuhkan modal yang cukup untuk membiayai keperluan dan kegiatannya. Untuk memenuhi kebutuhan tersebut tentunya akan dilakukan berbagai usaha. Pemenuhan kebutuhan ini dilakukan demi tetap berlangsungnya kegiatan ekonomi yang dijalankan. Ketika menjalankan kegiatan ekonomi adakalanya dimana usaha tersebut tidak berjalan dengan baik dikarenakan kurangnya modal untuk menjalankan dan memenuhi kebutuhan usahanya. Untuk dapat 
mencukupi kekurangan modal tersebut, orang atau perusahaan antara lain dapat melakukannya dengan meminjam atau memakai modal dari pihak lain sebagai cara untuk meningkatkan keuntungan yang dapat diraih, baik dilihat dari segi jumlah maupun dari segi waktu. ${ }^{1}$

Banyak cara yang tersedia bagi seseorang atau perusahaan yang ingin memperoleh pinjaman. Dari sumber-sumber dana itulah kekurangan dana tersebut dapat diperoleh. Kesepakatan pinjam-meminjam untuk memperoleh bantuan dana dari pihak ketiga ditindaklanjuti dengan membuat perjanjian yang disepakati para pihak pada waktu jatuh tempo sesuai dengan waktu yang diperjanjikan. ${ }^{2}$ Tuntutan wanprestasi akan muncul ketika debitor tidak dapat menepati janjinya untuk melakukan pembayaran sesuai dengan kesepakatan, karena usahanya tidak berjalan sesuai dengan rencana dan harapan. ${ }^{3}$ Berbagai pilihan diatur oleh hukum untuk menyelesaikan utang piutang yang terjadi, salah satu pilihan untuk menyelesaikan utang piutang yang terjadi adalah dengan cara menempuh pengajuan permohonan kepailitan atau melalui Penundaan Kewajiban Pembayaran Utang ("PKPU”) dengan cara ini diharapkan dapat menjamin keamanan dan kepentingan para pihak yang bersangkutan. ${ }^{4}$

Kepailitan dan Penundaan Kewajiban Pembayaran Utang di Indonesia diatur dalam Undang-Undang Nomor 37 Tahun 2004 tentang Kepailitan dan Penundaan Kewajiban Pembayaran Utang (untuk selanjutnya disebut "UU KPKPU"). Berdasarkan Pasal 1 angka 1 UU KPKPU kepailitan adalah sita umum atas semua kekayaan debitor pailit yang pengurusan dan pemberesannya dilakukan oleh Kurator di bawah pengawasan Hakim Pengawas. Sedangkan UU KPKPU tidak mendefinisikan secara eksplisit apa yang dimaksud dengan PKPU. Menurut pendapat Kartini Muljadi, PKPU merupakan suatu cara

\footnotetext{
${ }^{1}$ Pande Radja Silalahi, Dampak Perpu Kepailitan terhadap Dunia Usaha dalam Penyelesaian Utang Piutang Melalui Pailit atau Penundaan Kewajiban Pembayaran Utang, (Alumni 2003). [203-204].

2 Herry Anto Simanjuntak, ‘Penyelesaian Utang Debitur Terhadap Kreditur Melalui Kepailitan' (2019) 1 Jurnal Justiqa.[9].

${ }^{3}$ Anita Afriana dan Rai Mantili, 'Implementasi Perdamaian (Accord) Pada Pengadilan Niaga Dalam Penyelesaian Perkara Kepailitan Di Indonesia' (2017) 2 Jurnal Ilmiah Hukum.[221].

${ }^{4}$ Man. S. Sastrawidjaja, Hukum Kepailitan dan Penundaan Kewajiban Pembayaran Utang, cet. 1 (ALUMNUS 2006).[1].
} 
dimana debitor menawarkan rencana perdamaian kepada kreditornya untuk melakukan restrukturisasi utang-utangnya. ${ }^{5}$ Selain itu PKPU dapat disebut juga sebagai pranata yang memberikan kesempatan bagi debitor untuk menghindari kepailitan dengan cara melakukan restrukturisasi dalam bentuk proposal rencana perdamaian kepada para kreditor. ${ }^{6}$

Permohonan kepailitan dan PKPU diajukan kepada Pengadilan Niaga sebagai lembaga yang memiliki kewenangan untuk memeriksa perkara kepailitan dan PKPU berdasarkan UU KPKPU. Adapun perbedaan dari kepailitan yakni, kepailitan terjadi ketika seorang debitor dinyatakan atau dalam keadaan berhenti membayar utang-utangnya yang sudah jatuh tempo. Berbeda dengan PKPU, PKPU terjadi ketika debitor tidak dapat atau memperkirakan tidak akan dapat melanjutkan membayar utang-utangnya pada waktu yang sudah ditentukan. ${ }^{7}$

PKPU diatur dalam Pasal 222 hingga Pasal 264 UU KPKPU, dimana PKPU merupakan sarana penyelesaian sengketa utang-piutang yang dapat diajukan oleh debitor atau kreditor sebelum permohonan pernyataan pailit diajukan maupun setelah permohonan pernyataan pailit diajukan tetapi belum dijatuhkan putusan oleh Pengadilan. ${ }^{8}$ Dengan dikabulkannya Permohonan PKPU, debitor akan diberikan kesempatan untuk mengajukan rencana perdamaian. Pada saat debitor mengajukaan rencana perdamaian, kreditor mempunyai hak untuk menolak atau menerima rencana perdamaian yang diajukan. Adapun apabila mayoritas kreditor sepakat terhadap rencana perdamaian yang diajukan, maka rencana perdamaian tersebut tidak dapat segera dilaksanakan namun harus dilakukan pengesahan dari Pengadilan yang selanjutnya akan dituangkan dalam putusan homologasi. ${ }^{9}$

\footnotetext{
${ }^{5}$ Kartini Muljadi (et al), Penyelesaian Utang Piutang Melalui Pailit atau Penundaan Kewajiban Pembayaran Utang (Alumni 2001).[173].

${ }^{6}$ SSEK, 'Bankruptcy Law and Suspension of Debt Payments in Indonesia' http://www.gbgindonesia.com/en/main/legal_updates/bankruptcy_law_and_suspension_of_debt_payments_ in_indonesia.php, diakses 28 Februari 2020.

${ }^{7}$ Nyulistiowati Suryanti, Monograf Hukum Dagang (Logoz Publishing 2017).[4].

${ }^{8}$ Regina Nitami Kasdi, 'Analisis Putusan Pengadilan Niaga Terkait Akibat Hukum Permohonan Pkpu Yang Diajukan Oleh Pihak Yang Tidak Berwenang (Studi Kasus Putusan Pengadilan Niaga Pada Pengadilan Negeri Jakarta Pusat Nomor 24/Pdt.Sus-Pkpu/2018/Pn.Niaga.Jkt.Pst)' (2019) 2 Jurnal Hukum Adigama.[4].

${ }^{9}$ M. Hadi Subhan, Hukum Kepailitan: Prinsip, Norma, dan Praktik di Peradilan (Kencana 2008).[142].
} 
Adam Barnini, dkk: Kedudukan Kreditor yang...

Tujuan dilakukannya homologasi antara debitor dengan kreditur adalah untuk mencegah seorang debitor yang apapun sebabnya berada dalam kesulitan, kekurangan uang, atau sukar memperoleh kredit, sehingga kemudian dinyatakan pailit yang berakibat bahwa harta kekayaan dijual dan perusahaannya terpaksa dihentikan. Sedangkan jika perusahaan itu dapat terus dijalankan, debitor tidak kehilangan harta kekayaannya dan para kreditur mungkin mendapatkan pembayaran piutang mereka lebih memuaskan daripada jika debitor dinyatakan pailit. $^{10}$

Pada pasal 286 UU KPKPU dijelaskan bahwa Rencana Perdamaian yang telah disahkan mengikat semua kreditor kecuali kreditor yang piutangnya dijamin dengan gadai, jaminan fidusia, hak tanggungan, hipotek, atau hak agunan atas kebendaan lainnya maka akan diberikan kompensasi sebesar nilai terendah di antara nilai jaminan atau nilai aktual pinjaman yang secara langsung dijamin dengan hak agunan atas kebendaan. ${ }^{11}$ Dengan adanya ketentuan tersebut, artinya debitor wajib menawarkan rencana perdamaian tersebut kepada seluruh kreditornya agar terhindar dari adanya salah satu kreditor yang mengajukan permohonan pernyataan pailit tanpa memedulikan rencana perdamaian yang telah disahkan. ${ }^{12}$

Dalam tataran implementasinya, masih banyak dijumpai kreditor yang tidak dicantumkan mengenai kapan utang tersebut dibayarkan dan berapa jumlah utang yang akan dibayarkan dalam daftar piutang pada Rencana Perdamaian. Hal tersebut salah satunya dapat disebabkan piutang kreditor dianggap belum memenuhi unsur pembuktian sederhana sehingga tidak mendapatkan pengakuan utang dari debitor. Hal ini tentunya dapat menimbulkan permasalahan baru yaitu mengenai keterikatan kreditor yang piutangnya ditolak serta tidak dijadwalkan pembayarannya dalam rencana perdamaian yang telah disahkan sehingga

10 Tedy Herlambang, Nurwidiatmo, Taqiyuddin Kadira, 'Kepastian Hukum Pelaksanaan Eksekusi Terhadap Perjanjian Yang Telah Disahkan (Homologasi)' (2017) 3 Jurnal Nuansa Kenotariatan.[29].

${ }^{11}$ Pasal 286 UU KPKPU jo Pasal 281 ayat (1) UU KPKPU.

12 Sutan Remy Sjahdeini, Hukum Kepailitan: Memahami undang-undang No. 37 Tahun 2004 tentang Kepailitan (Pustaka Umum Grafiti 2010).[417]. 
kemudian kreditor tersebut mengajukan permohonan pernyataan pailit terhadap debitor dalam PKPU dan terhadap permohonan tersebut Hakim Pengadilan Niaga mengabulkannya.

Adanya putusan pailit yang dijatuhkan terhadap perusahaan yang sebelumnya sudah disahkan rencana perdamaiannya, menimbulkan pertanyaan mengenai kedudukan kreditor yang tidak terdaftar dalam Rencana Perdamaian yang telah disahkan dalam mengajukan permohonan pailit. Berdasarkan paparan singkat mengenai fenomena di atas, maka hal ini menimbulkan permasalahan penting untuk dikaji.

\section{Meteode Penelitian}

Artikel ini menggunakan metode penelitian yuridis normatif dengan merujuk pada bahan-bahan hukum tertulis dengan mengkaji data sekunder yang berupa bahan hukum primer, sekunder dan tersier ${ }^{13}$ yang berkaitan dengan kepailitan dan PKPU. Artikel ini menggunakan spesifikasi penelitian secara deskriptif analitis yaitu dengan cara menelaah ketentuan-ketentuan hukum yang bersangkutan dengan isu hukum terkait, yang kemudian dilakukan analisis secara kualitatif sehingga menghasilkan kesimpulan.

\section{Kedudukan Kreditor yang Tidak Terdaftar Pada Putusan Rencana Perdamaian PKPU dalam Mengajukan Permohonan Pernyataan Pailit}

PKPU merupakan pranata yang digunakan untuk menyelesaikan permasalahan utang-piutang. Beberapa faktor yang menyebabkan pranata PKPU ini dipilih untuk menyelesaikan permasalahan utang-piutang antara kreditor dengan debitor diantaranya adalah untuk menghindari kepailitan dan memberikan kesempatan kepada debitor untuk melanjutkan usahanya tanpa adanya desakan untuk melunasi utang-utangnya dalam bentuk penawaran rencana perdamaian. ${ }^{14}$

${ }^{13}$ Sunaryati Hartono, Penelitian Hukum Di Indonesia Pada Akhir Abad ke-20 (Alumni 1994).[140-143].

${ }^{14}$ Syamsudin M. Sinaga, Hukum Kepailitan Indonesia (PT Tatanusa 2008).[28]. 
Adam Barnini, dkk: Kedudukan Kreditor yang...

Adapun dengan diajukannya rencana perdamaian tersebut, terdapat dua kemungkinan yang dapat terjadi, yakni diterimanya rencana perdamaian oleh mayoritas kreditor atau ditolaknya rencana perdamaian oleh mayoritas kreditor. ${ }^{15}$ Apabila rencana perdamaian diterima, Hakim Pengawas wajib menyampaikan laporan tertulis kepada pengadilan niaga pada tanggal yang telah ditentukan untuk melaksanakan pengesahan perdamaian ${ }^{16}$ dikarenakan suatu perdamaian yang telah diterima tidak dapat langsung dilaksanakan akan tetapi harus dilakukan homologasi terlebih dahulu. ${ }^{17}$

Berdasarkan ketentuan dalam UU KPKPU, rencana perdamaian yang telah disahkan mengikat seluruh kreditor kecuali kreditor yang piutangnya dijamin dengan gadai, jaminan fidusia, hak tanggungan, hipotek, atau hak agunan atas kebendaan lainnya maka akan diberikan kompensasi sebesar nilai terendah di antara nilai jaminan atau nilai aktual pinjaman yang secara langsung dijamin dengan hak agunan atas kebendaan.

Dalam pelaksanaannya, tak jarang dijumpai kreditor yang merasa dirugikan akibat adanya putusan homologasi. Salah satu penyebabnya adalah kreditor tersebut tidak dijadwalkan pembayaran piutangnya dalam daftar piutang yang telah disusun oleh debitor dalam proposal rencana perdamaiannya, yang kemudian disahkan oleh Pengadilan. Hal demikian tentunya menimbulkan suatu keadaan yakni, kreditor yang merasa dirugikan akibat adanya putusan homologasi kemudian mengajukan permohonan pernyataan pailit dan atas permohonan pernyataan pailit tersebut Hakim mengabulkannya.

Peristiwa hukum tersebut terjadi pada Putusan Mahkamah Agung Nomor 708 K/Pdt.Sus-Pailit/2015., antara PT Siak Raya Timber dengan PT Nusantara Sentosa Raya dan Putusan Pengadilan Niaga Jakarta Pusat Nomor 20/Pailit/2009/ PN. Niaga Jkt. Pst., antara PT Rasico Industry dengan PT Panda Trading Indonesia.

\footnotetext{
${ }^{15}$ Ivan Harsono, 'Analisis Terhadap Perdamaian Dalam PKPU Dan Pembatalan Perdamaian Pada Kasus Kepailitan PT Njoja Meneer’ (2019) 12 Notarius.[1069].

${ }^{16}$ Jono, Hukum Kepailitan (Sinar Grafika 2008).[15].

${ }^{17}$ Hetty Tri Kusuma Indah, 'Perdamaian Dalam Proses Hukum Kepailitan' (2014) 4 Jurnal Hukum Uniski.[12].
} 
Kedua kasus tersebut membuktikan bahwa adanya keadaan dimana permohonan pernyataan pailit yang diajukan oleh salah satu kreditor terhadap debitor dalam PKPU dapat diterima, walaupun sebelumnya rencana perdamaian yang diajukan oleh debitor tersebut telah dihomologasi.

Mahkamah Agung dan Hakim Pengadilan Niaga Jakarta Pusat menerima permohonan pernyataan pailittersebutdengan pertimbanganbahwa permohonan yang diajukan telah memenuhi syarat untuk debitor dapat dinyatakan dalam keadaan pailit. Selain itu hakim juga memberikan pertimbangan bahwa kreditor yang mengajukan permohonan pernyataan pailit tersebut bukan merupakan pihak yang dimasukkan dan/atau terdapat dalam rencana perdamaian yang telah disahkan, oleh karenanya kreditor tersebut tidak terikat pada perjanjian perdamaian yang telah disahkan. Penerimaan permohonan pernyataan pailit tersebut nyatanya memberikan status hukum kepada kreditor untuk dapat menagih piutang kepada debitor diluar dari perjanjian perdamaian yang sebelumnya telah disepakati, sehingga hal ini dapat merugikan debitor dan kreditor lainnya.

Berangkat dari permasalahan di atas, penerimaan permohonan pernyataan pailit yang diajukan oleh kreditor yang tidak terdaftar dalam perjanjian perdamaian yang telah disahkan dinilai tidak tepat. Secara normatif apabila kita lakukan penafsiran secara sistematis dalam UU KPKPU ditemukan benang merah terkait dengan kedudukan kreditor terhadap rencana perdamaian debitor yang telah disahkan sehingga mengikat seluruh kreditor.

Pertama, bahwa pada saat debitor diputus dalam keadaan PKPU Sementara, ${ }^{18}$ Pengadilan melalui pengurus wajib melakukan dua hal yakni:

1) memanggil debitor dan kreditor melalui surat tercatat atau melalui kurir untuk menghadap dalam sidang;

2) mengumumkan putusan PKPU Sementara dalam Berita Negara RI dan dalam 2 surat kabar harian yang ditunjuk oleh hakim pengawas.

${ }^{18}$ Pasal 222 UU KPKPU. 
Surat dan pengumuman tersebut memuat mengenai undangan bagi debitor dan para kreditornya untuk hadir pada persidangan yang membahas mengenai proposal perdamaian yang telah atau akan diajukan oleh debitor. ${ }^{19}$ Di sisi lain, apabila terdapat kreditor yang tidak menerima panggilan untuk datang dalam sidang yang yang akan diselenggarakan, maka berdasarkan Pasal 228 ayat (2) UU KPKPU kreditor yang bersangkutan berhak untuk datang ke dalam sidang tersebut untuk mendapatkan hak-haknya. ${ }^{20} \mathrm{Hal}$ ini selaras dengan tujuan dibentuknya pengaturan mengenai PKPU yakni PKPU bukan hanya dapat diajukan kepada kreditor tertentu saja, tetapi kepada seluruh kreditor. ${ }^{21}$

Berkaitan dengan hal tersebut di atas, apabila terdapat kreditor yang tidak hadir dalam sidang yang membahas mengenai proposal rencana perdamaian, hingga proposal perdamaian tersebut disahkan oleh Pengadilan adalah merupakan kesalahannya sendiri dan berimplikasi pada hilangnya hak kreditor untuk melakukan negosiasi dengan pengurus dan debitor terhadap tata cara penyelesaian piutangnya. Namun pada umumnya, terhadap kreditor yang tidak mengajukan tagihannya, baik itu kreditor separatis atau konkuren, akan ditentukan tata cara penyelesaiannya dalam rencana perdamaian debitor sesuai dengan klasifikasi kreditor dalam perjanjian perdamaian. ${ }^{22}$

Kedua, berdasarkan ketentuan Pasal 232 ayat (1) dan (3) UU KPKPU, panitera wajib membuat daftar umum untuk setiap PKPU yang berisi mengenai tanggal putusan penundaan kewajiban pembayaran utang sementara dan tanggal putusan penundaan kewajiban pembayaran utang tetap berikut perpanjangannya; kutipan putusan Pengadilan yang menetapkan penundaan kewajiban pembayaran utang sementara maupun yang tetap dan perpanjangannya; nama Hakim Pengawas dan Pengurus yang diangkat; ringkasan isi perdamaian dan pengesahan perdamaian tersebut di Pengadilan; dan pengakhiran perdamaian, yang kemudian terhadap

${ }^{19}$ M. Hadi Shubhan, Op.Cit.[148].

${ }^{20}$ Pasal 228 ayat (2) UU KPKPU

${ }^{21}$ Sutan Remy Sjahdeini, Op. Cit. [417].

${ }^{22}$ Alfin Sulaiman, 'Jika Nama Kreditor Tak Terdaftar Dalam Putusan Perdamaian PKPU' https:// www.hukumonline.com/klinik/detail/ulasan/lt57d110ea03f49/jika-nama-kreditor-takterdaftar-dalam-putusan-perdamaian-pkpu, diakses pada 2 Februari 2020. 
daftar umum tersebut terbuka bagi umum dan dapat diperiksa oleh siapapun tanpa dipungut biaya. ${ }^{23}$

Sehubungan dengan ketentuan di atas, UU KPKPU telah memberikan informasi kepada setiap orang secara cuma-cuma dan memberikan kesempatan kepada pihak yang berkepentingan khususnya kreditor dari debitor yang sudah diputus dalam keadaan PKPU Sementara untuk dapat berpartisipasi dalam proses penyelasain utang-piutang debitor dalam PKPU. Namun, apabila hingga rencana perdamaian tersebut disetujui dan disahkan oleh pengadilan, kreditor yang berkepentingan tidak berpartisipasi terhadap penyelesaian utang-piutang debitor, maka kreditor tersebut dinilai telah melepaskan haknya dalam menentukan apakah rencana perdamaian yang diajukan oleh debitor layak diterima atau tidak. ${ }^{24}$ Tetapi walaupun kreditor telah kehilangan hak suaranya dalam voting rencana perdamaian, kreditor tersebut tetap memiliki hak untuk mendapatkan pembayaran piutangnya dari debitor sesuai dengan status kreditornya dalam perjanjian perdamaian.

Ketiga, selama proses PKPU berlangsung debitor diberikan hak untuk menyusun proposal rencana perdamaian. Rencana perdamaian yang diajukan oleh debitor haruslah disusun sedemikian rupa sehingga para kreditor akan bersedia untuk menerima rencana perdamaian tersebut. ${ }^{25}$ Berdasarkan Pasal 281 UU KPKPU, diterima atau ditolaknya suatu rencana perdamaian dilakukan dengan menggunakan mekanisme voting, yakni yang berhak untuk memutuskan diterima atau ditolaknya rencana perdamaian adalah mereka yang mempunyai hak suara dalam rapat, yaitu para kreditor konkuren dan para kreditor separatis yang hadir dalam rapat. ${ }^{26}$

Berkaitan dengan pemungutan suara proposal recanan perdamaian, bagi kreditor yang tidak hadir dalam rapat tidak memiliki pengaruh terhadap

\footnotetext{
${ }^{23}$ Pasal 232 ayat (1) dan (3) UU KPKPU.

${ }^{24}$ Jerome Sgard, 'Bankruptcy Law: Majority Rule and Private Ordering in England and French (Seventeenth-Nineteenth)' http:/ / www.oxpo.politics.ox.ac.uk, diakses pada 2 Februari 2021.

${ }^{25}$ Sutan Remy Sjahdeini, Op. Cit. [457].

${ }^{26}$ Pasal 281 UU KPKPU.
} 
diterima atau ditolaknya perdamaian tersebut, walaupun jumlahnya signifikan. Ratio legis dari ketentuan ini adalah bahwa kreditor yang tidak hadir dianggap telah melepaskan hak (rechtsverwerking) sehingga akan menerima keputusan apapun yang diambil. ${ }^{27}$ Artinya, kreditor tersebut tetap terikat dengan perjanjian perdamaian yang telah disahkan dan tetap akan mendapatkan pembayaran piutangnya dari debitor yang sudah disahkan perjanjian perdamaiannya.

Keempat, rencana perdamaian yang telah disetujui tidak dapat langsung dilaksanakan, diperlukan tahapan selanjutnya yakni pengesahan oleh Pengadilan. Berdasarkan Pasal 286 UU KPKPU, rencana perdamaian yang telah disahkan mengikat seluruh kreditor kecuali kreditor yang dijamin dengan hak kebendaan yang menolak rencana perdamaian. Seluruh kreditor yang dimaksud adalah baik kreditor konkuren maupun preferen, baik kreditor baik kreditor yang menyetujui atau yang menolak rencana perdamaian. ${ }^{28}$ Bahkan mengikat juga bagi kreditor yang hadir maupun yang tidak hadir dalam rapat yang membicarakan mengenai perdamaian tersebut. ${ }^{29}$

Konsekuensinya, dengan adanya perjanjian perdamaian hubungan antara debitor dan para kreditornya tidak lagi diatur dengan ketentuan dalam masing-masing perjanjian bilateral sebelumnya, tetapi diatur dengan syarat dan ketentuan dalam perjanjian perdamaian itu. Perjanjian bilateral antara para pihak sebelumnya menjadi tidak berlaku setelah perjanjian perdamaian disahkan oleh pengadilan niaga. ${ }^{30}$

Maka dari itu, berlakunya suatu perdamaian hanya mempunyai arti jika seluruh kreditor terikat dengan perdamaian tersebut. Apabila perdamaian ditentukan hanya berlaku bagi kreditor tertentu, ternyata terdapat salah satu

${ }^{27}$ M. Hadi Shubhan, Op.Cit.[141].

${ }^{28}$ Lontoh, Rudy A; Kailimang, Denny \& Ponto, Penyelesaian Utang Piutang: Melalui Pailit atau Penundaan Kewajiban Pembayaran Utang, (Penerbit Alumni 2001); Setiawan, Ordonasi Kepailitan Serta Aplikasi Kini, Dalam Lontoh, Rudy A., dkk, Penyelesaiaan Utang piutang: Melalui Pailit atau Penundaan Kewajiban Pembayaran Utang (Penerbit Alumni 2001)

${ }^{29}$ Teukoe Hermanshah, 'Penundaan Kewajiban Pembayaran Utang Dalam Rangka Mencegah Kepailitan' (2018) XVII Law Review.[222].

${ }^{30}$ Hary Azhari, 'Akibat Hukum Kelalaian Debitor Untuk Memenuhi Perjanjian Perdamaian Dalam PKPU (Studi Putusan Mahakamah Agung Nomor 376/K/Pdt.Sus-Pailit/2017)' Skripsi, (Universitas Sumatera Utara).[65]. 
kreditor yang mengajukan permohonan pernyataan pailit tanpa memedulikan perjanjian perdamaian dan permohonan itu ternyata dikabulkan oleh pengadilan, maka senyatanya hal tersebut sangat merugikan dan membahayakan kedudukan debitor dan kepentingan para kreditor lainnya.

Berangkat dari kedua kasus di atas, sejatinya apabila rencana perdamaian yang diajukan debitor telah disepakati oleh mayoritas kreditor dan kemudian telah disahkan oleh Pengadilan, maka seluruh kreditor dari debitor, baik yang menyetujui maupun menolak, baik kreditor yang hadir maupaun tidak hadir, baik kreditor separatis mauapun konkuren, tetap terikat dengan perjanjian perdamaian tersebut dan tetap mendapatkan haknya sesuai dengan status kreditornya. Dengan demikian, Hakim seharusnya menolak permohonan pernyataan pailit yang diajukan terhadap debitor tersebut. Namun dapat melakukan upaya hukum lainnya yakni dengan mengajukan permohonan pembatalan perjanjian perdamaian. ${ }^{31}$

\section{Kekuatan Hukum Putusan Homologasi Terhadap Kreditor Yang Tidak Terdaftar Dalam Perjanjian Perdamaian PKPU}

Homologasi merupakan suatu tahapan dimana Pengadilan Niaga melakukan pengesahan terhadap perdamaian yang telah disetujui oleh kreditor. ${ }^{32}$ Adanya homologasi terhadap perjanjian perdamaian yang telah disahkan merupakan hal yang penting dalam proses PKPU. Hal tersebut dikarenakan debitor dapat merestrukturisasi utang-utangnya sehingga dapat terus berusaha dan dapat membayarkan utang-utangnya serta terhindar dari pailit. ${ }^{33}$ Dengan dihomologasinya perjanjian perdamaian, maka seluruh kreditor terikat dengan

${ }^{31}$ Chairul Maksus Syam, 'Praktek Eksekusi Aset Perusahaan Debitor Pailit Menurut UndangUndang Nomor 37 Tahun 2004 Tentang Kepailitan Dan Penundaan Kewajiban Pembayaran Utang (Studi Kasus Putusan Nomor 11/Pdt.Sus-Pailit/2017/ Pn.Niaga.Smg)' (2020) 3 Jurnal Hukum Adigama.[626].

${ }^{32}$ Ivan Harsono, Paramita Prananingtyas, 'Analisis Terhadap Perdamaian Dalam PKPU Dan Pembatalan Perdamaian Pada Kasus Kepailitan PT Njoja Meneer' (2019) 12.[1067].

33 Cholifatun Nisa, 'Akibat Hukum Pengesahan Perdamaian (Homologasi) Terhadap Penundaan Kewajiban Pembayaran Utang Dalam Hal Debitornya Perseroan Terbatas' (2019) 2 Jurnal Jurist-Diction.[426]. 
Adam Barnini, dkk: Kedudukan Kreditor yang...

perjanjian perdamain tersebut. Hal ini sesuai dengan ketentuan Pasal 286 UU KPKPU yang menyatakan bahwa "Perdamaian yang telah disahkan mengikat semua kreditor, kecuali kreditor yang tidak menyetujui rencana perdamaian sebagaimana dimaksud dalam Pasal 281 ayat (2)".

Akibatnya, timbul hak dan kewajiban yang harus dipenuhi oleh debitor maupun kreditor sesuai dengan isi perjanjian perdamaian yang telah disepakati oleh mayoritas kreditor. Seluruh kreditor yang dimaksud dalam pasal tersebut tentunya merupakan, seluruh kreditor tanpa terkecuali, baik kreditor konkuren maupun kreditor preferen, baik kreditor yang menyetujui atau yang menolak rencana perdamaian, baik kreditor yang hadir maupun yang tidak hadir dalam rapat yang membicarakan mengenai perdamaian tersebut.

Namun, pada prakteknya tak jarang dijumpai terdapat kreditor-kreditor yang merasa dirugikan akibat ketidakhadirannya dalam proses PKPU hingga Perjanjian Perdamaian PKPU disahkan Pengadilan Niaga, sehingga tagihan kreditor tidak dimasukkan mengenai berapa dan kapan utang tersebut dibayarkan pembayarannya dalam rencana perdamaian. Salah satu alasannya adalah kreditor tidak mengetahui bahwa debitornya sedang berada dalam proses PKPU. Hal tersebut membuat kreditor merasa tidak terikat dengan perjanjian perdamain yang telah disetujui dan kemudian disahkan oleh Pengadilan.

Hal demikian terjadi pada Putusan Mahkamah Agung dengan Nomor 708 K/Pdt.Sus-Pailit/2015., antara PT Siak Raya Timber dengan PT Nusantara Sentosa Raya. Selaku kreditor, PT Nusantara Sentosa Raya merasa dirugikan dengan adanya putusan homologasi. Hal tersebut dikarenakan piutang yang diajukan oleh PT Nusantara Sentosa Raya tidak dijadwalkan pembarannya dalam daftar piutang pada perjanjian perdamaian, dengan alasan masih dalam proses hukum Arbitrase Singapura sehingga harus menunggu kejelasan terhadap piutang tersebut.

Kasus lain terjadi juga pada Putusan Pengadilan Niaga Jakarta Pusat Nomor 20/Pailit/2009/PN. Niaga Jkt. Pst., antara PT Rasico Industry dengan PT Panda Trading Indonesia. Dalam kasus ini, piutang yang dimiliki oleh PT Panda Trading Indonesia selaku kreditor dari PT Rasico Industry tidak dimasukkan oleh PT 
Rasico Industry ke dalam rencana perdamaian yang telah disusun olehnya, yang kemudian disepakati oleh mayoritas kreditor dan disahkan oleh Pengadilan. Keadaan tersebut membuat PT Panda Trading Indonesia merasa sangat dirugikan akibat adanya putusan homologasi tersebut.

Sebagaimana yang telah diuraikan di atas, pada dasarnya perjanjian perdamaian yang telah disahkan mengikat seluruh kreditor, baik kreditor konkuren maupun kreditor preferen, baik kreditor yang menyetujui atau yang menolak rencana perdamaian, baik kreditor yang hadir maupun yang tidak hadir dalam rapat perdamaian. Oleh karena itu, apabila terdapat kreditor yang tidak mengikutsertakan dirinya dalam proses PKPU berlangsung hingga perdamaian disahkan, in casu PT Panda Trading Indonesia yang merupakan kreditor dari PT Rasico Industry, dianggap telah melepaskan hak suaranya sebagai kreditor yang akan menentukan apakah rencana perdamaian tersebut layak diterima atau tidak. Hal demikian juga selaras dengan ketentuan Pasal 281 UU KPKPU yang berbunyi:

1) Persetujuan lebih dari $1 / 2$ (satu perdua) jumlah kreditor konkuren yang haknya diakui atau sementara diakui yang hadir pada rapat kreditor, yang bersamasama mewakili paling sedikit 2/3 (dua pertiga) bagian dari seluruh tagihan yang diakui atau sementara diakui dari kreditor konkuren atau kuasanya yang hadir dalam rapat kreditor tersebut; dan

2) Persetujuan lebih dari $1 / 2$ (satu perdua) jumlah kreditor yang piutangnya dijamin dengan gadai, jaminan fidusia, hak tanggungan, hipotek atau hak agunan atas kebendaan lainnya yang hadir dan mewakili paling sedikit 2/3 (dua pertiga) bagian dari seluruh tagihan dari kreditor tersebut atau kuasanya yang hadir dalam rapat tersebut.

Adanya mekanisme voting pada rencana perdamaian, menunjukkan bahwa terhadap kreditor yang tidak hadir dalam proses perdamaian dan/ atau voting terhadap rencana perdamaian yang ditawarkan debitor PKPU, sehingga kemudian kreditor tersebut tidak terdaftar dalam rencana perdamaian, seberapapun jumlahnya atau sebesar apapun piutang mereka, hal tersebut sama 
sekali tidak mempengaruhi sahnya pengambilan keputusan. ${ }^{34}$ Namun demikian terhadap kreditor tersebut harus tetap menerima hasil keputusan voting rencana perdamaian dan tetap terikat pada rencana perdamaian tersebut. Alasannya, pada perkara PKPU, kepentingan yang dilihat tidak hanya terhadap satu kreditor saja, melainkan banyak kreditor lain yang terlibat juga.

Dengan disetujuinya perdamaian oleh mayoritas kreditor, maka terhadap kreditor yang tidak terdaftar pada perjanjian perdamaian akan tetap terikat pada perjanjian perdamain tersebut. Ratio legis dari ketentuan tersebut adalah jika tidak semua kreditor terikat dengan perjanjian perdamaian yang telah disahkan maka kedudukan debitor dan kreditor lainnya akan dibahayakan atau dirugikan apabila terdapat salah satu kreditor yang mengajukan permohonan penyataan pailit. ${ }^{35}$

Selanjutnya, pada saat rencana perdamaian telah disetujui dan kemudian disepakati oleh mayoritas kreditor, Hakim pengawas wajib menyampaikan laporan tertulis kepada Pengadilan Niaga pada tanggal yang telah ditentukan untuk melaksanakan pengesahan perdamaian. ${ }^{36}$ Perihal pengesahan rencana perdamaian oleh Pengadilan, hakim bebas untuk menerima atau mengesahkan atau untuk menolak memberikan pengesahan terhadap reorganization plan tanpa harus memperhatikan apakah plan itu telah disetujui atau telah ditolak oleh para kreditor dalam negosiasi kesepakatan antara debitor dan para kreditornya. Alasan yang dapat digunakan hakim untuk menolak rencana perdamaian diantaranya: ${ }^{37}$

1) Harta debitor termasuk benda yang digunakan hak untuk menahan suatu benda jauh lebih besar dibandingkanjumlah yang disetujui dalam perdamaian;

2) Pelaksanaan dari perdamaian tidak cukup terjamin;

3) Perdamaian dicapai karena adanya penipuan atau persekongkolan dengan satu atau lebih kreditor atau adanya upaya lain yang tidakjujur dan tanpa menghiraukan apakah debitor atau pihak lain bekerja sama untuk mencapai perdamaian.

\footnotetext{
${ }^{34}$ Ishak, 'Perdamaian Antara Debitor Dan Kreditor Konkuren Dalam Kepailitan' (2016) 18 Kanun Jurnal Ilmu Hukum.[149].

${ }^{35}$ Sutan Remy Sjahdeini, Op.Cit.[417].

${ }^{36}$ Jono, Hukum Kepailitan (Sinar Grafika 2008).[15].

${ }^{37}$ Pasal 159 ayat (2) UU KPKPU.
} 
Selain daripada itu, keputusan Pangadilan Niaga untuk menolak atau mengesahkan perjanjian perdamain diambil setelah terlebih dahulu melakukan dengar pendapat dengan pihak-pihak yang bersangkutan dan hasil dengar pendapat ini nantinya memberi kesempatan bagi kreditor dan debitor untuk mengajukan keberatan jika masih ada keberatan yang dijumpai. ${ }^{38}$ Hal demikian dilakukan agar rencana perdamaian yang telah diputus oleh Pengadilan Niaga nantinya benar-benar kokoh untuk mengikat dan dilaksanakan oleh para pihak. ${ }^{39}$

Dengan demikian sejatinya UU KPKPU telah memberikan kesempatan kepada debitor dan kreditor untuk menegosiasikan rencana perdamaian yang diajukan oleh debitor hingga perdamaian tersebut disetujui. Kemudian UU KPKPU juga telah memberikan ruang Hakim Pengadilan Niaga untuk menilai apakah isi dari perjanjian perdamaian sudah seimbang antara kepentingan debitor dan kreditor. Artinya, dengan diberikannya kesempatan kepada debitor dan kreditor untuk menyampaikan pendapatnya sebelum dilakukannya pengesahan perjanjian perdamaian serta diberikannya kewenangan kepada Hakim Pengadilan Niaga untuk kembali memeriksa apakah isi perdamaian telah menguntungkan bagi masing-masing pihak atau tidak, maka tentunya perjanjian perdamaian yang telah disahkan memiliki kekuatan hukum yang mengikat untuk dilaksanakan bagi debitor dan seluruh kreditornya, baik kreditor konkuren maupun kreditor preferen, baik kreditor yang menyetujui atau yang menolak rencana perdamaian, baik kreditor yang hadir maupun yang tidak hadir dalam rapat yang membicarakan mengenai perdamaian tersebut.

\section{Kesimpulan}

Perjanjian perdamaian yang telah disetujui oleh debitor dan mayoritas kreditor dan kemudian disahkan oleh Pengadilan Niaga, pada dasarnya memiliki

${ }^{38}$ Kemala Atika Hayati, 'Hak Suara Kreditor Separatis Dalam Proses Pengajuan Upaya Perdamaian Menurut Undang-Undang Nomor 37 Tahun 2004 Tentang Kepailitan Dan Penundaan Kewajiban Pembayaran Utang' (2016) 4 USU Law Journal.[120].

${ }^{39}$ Sriwijiastuti, 'Lembaga PKPU Sebagai Sarana Restrukturisasi Utang Bagi Debitor Terhadap Para Kreditor (Studi Kasus Pada PT. Anugerah Tiara Sejahtera)’ Tesis (Universitas Diponegoro 2010).[54]. 
kekuatan hukum yang mengikat pada seluruh kreditor, baik kreditor konkuren maupun kreditor preferen, baik kreditor yang menyetujui atau yang menolak rencana perdamaian, baik kreditor yang hadir maupun yang tidak hadir pada proses perdamaian dan/atau voting. Oleh karenanya, dengan telah disahkannya perjanjian perdamaian, hubungan antara debitor dan kreditor tidak lagi diatur dalam perjanjiannya masing-masing, namun segala hak dan kewajiban antara debitor dengan seluruh kreditornya diatur dalam perjanjian perdamaian tersebut.

Secara eksplisit UU KPKPU tidak memberikan larangan kepada kreditor untuk mengajukan permohonan pernyataan pailit terhadap debitor yang sebelumnya sudah disahkan perjanjian perdamaiannya. Jika dilakukan penafsiran secara sistematis terhadap UU KPKPU, maka sejatinya kreditor tidak dapat mengajukan permohonan pernyataan pailit terhadap debitor yang sebelumnya sudah dihomologasi perjanjian perdamaiannya. Namun jika permohonan pernyataan pailit tersebut diterima tanpa memperdulikan perjanjian perdamaian, kedudukan debitor dan kepentingan kreditor lain dapat dirugikan dan/atau dibahayakan. Hal demikian tentunya tidak memberikan keadilan dan kepastian hukum dakam upaya penyelesaian sengketa utang piutang.

Mengingat masih banyak putusan Pengadilan Niaga maupun Mahkamah Agung yang menerima permohonan pernyataan pailit terhadap debitor yang sebelumnya sudah disahkan perjanjian perdamaiannya, maka seharusnya untuk mencegah hal tersebut diperlukan revisi terhadap Undang-Undang Nomor 37 Tahun 2004 tentang Kepailitan dan Penundaan Kewajiban Pembayaran Utang agar terdapat pengaturan yang lebih tegas terkait dengan kekuatan hukum mengikat putusan homologasi terhadap debitor dan kreditornya sehingga dapat memberikan kepastian dan keadilan dalam rangka penyelesaian sengketa utang piutang.

\section{Daftar Bacaan}

\section{Buku}

Jono, Hukum Kepailitan (Sinar Grafika 2008).

Kartini Muljadi (et al), Penyelesaian Utang Piutang Melalui Pailit atau Penundaan 
Kewajiban Pembayaran Utang (Alumni 2001).

M. Hadi Subhan, Hukum Kepailitan: Prinsip, Norma, dan Praktik di Peradilan (Kencana 2008).

Man S. Sastrawidjaja, Hukum Kepailitan dan Penundaan Kewajiban Pembayaran Utang, cet. 1 (ALUMNUS 2006).

Nyulistiowati Suryanti, Monograf Hukum Dagang (Logoz Publishing 2017).

Pande Radja Silalahi, Dampak Perpu Kepailitan terhadap Dunia Usaha dalam Penyelesaian Utang Piutang Melalui Pailitatau Penundaan Kewajiban Pembayaran Utang (Alumni 2003).

Rudy A Lontoh; dkk, Penyelesaian Utang Piutang: Melalui Pailit atau Penundaan Kewajiban Pembayaran Utang (Penerbit Alumni 2001); Setiawan, Ordonasi Kepailitan Serta Aplikasi Kini, Dalam Rudy A Lontoh, dkk, Penyelesaiaan Utang piutang: Melalui Pailit atau Penundaan Kewajiban Pembayaran Utang (Penerbit Alumni 2001).

Sunaryati Hartono, Penelitian Hukum Di Indonesia Pada Akhir Abad ke-20 (Alumni 1994).

Sutan Remy Sjahdeini, Hukum Kepailitan: Memahami undang-undang No. 37 Tahun 2004 tentang Kepailitan (Pustaka Umum Grafiti 2010).

Syamsudin M. Sinaga, Hukum Kepailitan Indonesia (PT Tatanusa 2008).

\section{Jurnal}

Anita Afriana dan Rai Mantili, 'Implementasi Perdamaian (Accord) Pada Pengadilan Niaga Dalam Penyelesaian Perkara Kepailitan Di Indonesia' (2017) 2 Jurnal Ilmiah Hukum.

Chairul Maksus Syam, 'Praktek Eksekusi Aset Perusahaan Debitor Pailit Menurut Undang-Undang Nomor 37 Tahun 2004 Tentang Kepailitan Dan Penundaan Kewajiban Pembayaran Utang (Studi Kasus Putusan Nomor 11/Pdt.SusPailit/2017/ Pn.Niaga.Smg)' (2020) 3 Jurnal Hukum Adigama.

Cholifatun Nisa, 'Akibat Hukum Pengesahan Perdamaian (Homologasi) Terhadap Penundaan Kewajiban Pembayaran Utang Dalam Hal Debitornya Perseroan Terbatas' (2019) 2 Jurnal Jurist-Diction .

Herry Anto Simanjuntak, 'Penyelesaian Utang Debitur Terhadap Kreditur Melalui Kepailitan' (2019) 1 Jurnal Justiqa. 
Adam Barnini, dkk: Kedudukan Kreditor yang...

Hetty Tri Kusuma Indah, 'Perdamaian Dalam Proses Hukum Kepailitan' (2014) 4 Jurnal Hukum Uniski.

Ishak, 'Perdamaian Antara Debitor Dan Kreditor Konkuren Dalam Kepailitan' (2016) 18 Kanun Jurnal Ilmu Hukum.

Ivan Harsono dan Paramita Prananingtyas, 'Analisis Terhadap Perdamaian Dalam PKPU Dan Pembatalan Perdamaian Pada Kasus Kepailitan PT Njoja Meneer' (2019) 12.

Ivan Harsono, 'Analisis Terhadap Perdamaian Dalam PKPU Dan Pembatalan Perdamaian Pada Kasus Kepailitan PT Njoja Meneer' (2019) 12 Notarius.

Kemala Atika Hayati, 'Hak Suara Kreditor Separatis Dalam Proses Pengajuan Upaya Perdamaian Menurut Undang-Undang Nomor 37 Tahun 2004 Tentang Kepailitan Dan Penundaan Kewajiban Pembayaran Utang' (2016) 4 USU Law Journal.

Regina Nitami Kasdi, 'Analisis Putusan Pengadilan Niaga Terkait Akibat Hukum Permohonan Pkpu Yang Diajukan Oleh Pihak Yang Tidak Berwenang (Studi Kasus Putusan Pengadilan Niaga Pada Pengadilan Negeri Jakarta Pusat Nomor 24/Pdt.Sus-Pkpu/2018/Pn.Niaga.Jkt.Pst)' (2019) 2 Jurnal Hukum Adigama.

Tedy Herlambang, dkk, 'Kepastian Hukum Pelaksanaan Eksekusi Terhadap Perjanjian Yang Telah Disahkan (Homologasi)’ (2017) 3 Jurnal Nuansa Kenotariatan.

Teukoe Hermanshah, 'Penundaan Kewajiban Pembayaran Utang Dalam Rangka Mencegah Kepailitan’ (2018) Law Review XVII.

\section{Putusan}

Putusan Mahkamah Agung Nomor 708 K/Pdt.Sus-Pailit/2015 tentang Permohonan Banding Kepailitan antara PT Siak Raya Timber dengan PT Nusantara Sentosa, 27 November 2015.

Putusan Pengadilan Niaga Jakarta Pusat Nomor 20/Pailit/2009/PN. Niaga Jkt. Pst. tentang Permohonan Pernyataan Kepailitan antara PT Rasico Industry dengan PT Panda Trading Indonesia, 24 Juni 2009.

\section{Karya Ilmiah}

Hary Azhari, 'Akibat Hukum Kelalaian Debitor Untuk Memenuhi Perjanjian Perdamaian Dalam PKPU (Studi Putusan Mahakamah Agung Nomor 376/K/Pdt. 
Sus-Pailit/2017) Skripsi (Universitas Sumatera Utara 2017).

Sriwijiastuti, 'Lembaga PKPU Sebagai Sarana Restrukturisasi Utang Bagi Debitor Terhadap Para Kreditor (Studi Kasus Pada PT. Anugerah Tiara Sejahtera) Tesis (Universitas Diponegoro 2010).

\section{Laman}

Jerome Sgard, "Bankruptcy Law: Majority Rule and Private Ordering in England and French (Seventeenth-Nineteenth)", http:// www.oxpo.politics.ox.ac.uk, diakses pada 2 Februari 2021.

Sulaiman, Alfin, "Jika Nama Kreditor Tak Terdaftar Dalam Putusan Perdamaian PKPU",https:/ / www.hukumonline.com/klinik/detail/ulasan/ lt57d110ea03f49/jika-nama-kreditor-tak-terdaftar-dalam-putusanperdamaian-pkpu, diakses pada 2 Februari 2018.

SSEK, "Bankruptcy Law and Suspension of Debt Payments in Indonesia", http:/ / www.gbgindonesia.com/en/main/legal_updates/bankruptcy_law_and_ suspension_of_debt_payments_in_indonesia.php, diakses 28 Februari 2020.

\section{Perundang-undangan}

Undang-Undang Nomor 37 Tahun 2004 tentang Kepailitan dan Penundaan Kewajiban Pembayaran Utang.

How to cite: Adam Barnini, Nyulistiowati Suryanti dan Artaji, 'Kedudukan Kreditor yang Tidak Terdaftar Pada Putusan Perdamaian PKPU Dalam Mengajukan Permohonan Pernyataan Pailit' (2021) Vol. 4 No. 2 Media Iuris. 
--Halaman ini sengaja dibiarkan kosong-- 